\title{
ÉRTÉKESÍTŐI MOTIVÁCIÓK - KÜLÖNÖS TEKINTETTEL A PÉNZÜGYI, BIZTOSÍTÁSI TEVÉKENYSÉG NEMZETGAZDASÁGI ÁGRA
}

A cikk a pénzügyi, biztosítási tevékenység nemzetgazdasági ágban foglalkoztatott értékesítők motivációit vizsgálja Herzberg és McClelland motivációs elméleteire alapozva. A szerző először összegzi a kapcsolódó hazai és nemzetközi kutatási eredményeket, majd bemutatja a vizsgált nemzetgazdasági ág 1000 üzletkötőjének mintáján felvett saját kutatás vizsgálati eredményeit. A kutatás során összehasonlította az egyes ágazatok (banki, biztosítási, pénzügyi tanácsadói, lakástakarék-pénztári, faktoring, lízing, takarékszövetkezeti és tőzsdei) üzletkötőinek kérdőívben elért eredményeit is.

Ezen eredmények rámutatnak arra, hogy a vizsgált minta üzletkötői számára - a Motiváció - Mit várnak az emberek a munkájuktól? kérdőívben elért átlageredmények alapján - a higiénés tényezők jelentenek nagyobb „hajtóerőt” a motivátorokkal szemben. Megállapítható továbbá az is, hogy a mintát alkotó értékesítők esetében - a Motiváció - Mi motiválja Önt? kérdőívben elért átlageredmények alapján - a teljesítménymotiváció jelenti a legnagyobb ösztönzést a kapcsolattartás és a hatalommotivációkkal szemben. ${ }^{1}$

Kulcsszavak: motiváció, üzletkötők, pénzügy, biztosítás

$\mathrm{V}$ ajon milyen módon, milyen eszközök segítségével tudják motiválni munkavállalóikat a vállalatok? Különösen érdekes ez a kérdés, amennyiben a nagy teljesítményt követelö és jelentős stresszel járó üzletkötői/ értékesítői munkakört vesszük górcső alá. Ha mindezt a mai Magyarország pénzügyi, biztosítási tevékenység nemzetgazdasági ágára szűkítjük, még izgalmasabb és ágazatspecifikusabb eredményekre számíthatunk. Jelen tanulmány arra keresi a választ, hogy e nemzetgazdasági ág és ágazatainak értékesítői milyen motiváló és ösztönző komponensek meglétének biztosítását várják el munkaadóiktól, különös tekintettel a herzbergi és mcClellandi motivációs elméletekre és tényezőikre.

A kutatási témához kapcsolódó motivációs elméletek bemutatása előtt tisztázni kell, mit is takar maga a kifejezés: motiváció. A motiváció latin eredetü szó, melynek szótári alakja a következő: moveõ 2 mõvi, mõtus. Jelentése magyarul: mozgat, mozog. Lehetséges fogalmi meghatározásait az alábbiakban tekintem át. „A motiváció néven összefoglalt személyiségvonások is szükségesek a meglévő adottságok-képességek minél teljesebb valóra váltásához. A motiváció fogalma magában foglalja a szorgalmat, az akaratot, a kitartást, a feladat iránti elkötelezettséget, a megszállottságot és a sikervágyat. Tulajdonképpen a motiváció jelenti azt az energiatöbbletet, ami egy feladat kivételes szintű megoldásához kell, és amit az érzelmek számottevően befolyásolnak" (Tóth, 2007, p. 2). Egy másik megfogalmazás szerint „motivációnak nevezzük azt a ciklikus folyamatot, amely befolyásolja azon belső szükségleteket és hajtóerőket, amelyek kiváltják, irányítják és fenntartják az alkalmazottak teljesítményre irányuló eröfeszítését" (Dobák \& Antal, 2010, p. 349). Krasz úgy véli, hogy ,a motiváció magában foglalja a viselkedés irányítását, energizálását és a viselkedés megvalósulásának a mód- ját. A motívum maga a cselekvésre késztető belső tényező. A motiváció általában addig marad fenn, amíg a cselekvésre késztető tényezők, a motívumok nem nyernek kielégülést, tehát a motívum saját maga megszüntetése érdekében energizálja és irányítja a viselkedést" (Krasz, 2009, p. 50).

A legtöbb munkáltatónak az a célja, hogy legjobb munkavállalói nála tapasztalják meg az optimális motiváció szintjét. Ekkor ugyanis dolgozóik elérik azt a jólétérzést, vitalitást, pozitív energiatöbbletet, melynek révén töretlenül új és észszerü célokat tüznek ki maguk elé és meg is valósítják azokat, miközben folyamatosan gyarapodnak és fejlődnek (Fowler, 2015, p. 28). Természetesen a motiválás és a motiválhatóság rengeteg összetevő függvénye: a motiválás - és annak eszközei - függhetnek az elvégzendő projekttől, a munkavégzés feltételeitől (például attól, hogy egyénileg vagy csoportban kell elvégezni), de függhet a szervezeti kultúrától, az illető személyiségétől továbbá az egyén belső drivereitől stb. (Juhász, 2014a, p. 80.). A munkavállalók motiválásának számos alternatívája létezik. De még a motiválásban oly professzionálisan müködő multinacionális társaságok is sokszor szembesülnek azzal a többek között kulturális különbségekből fakadó - ténnyel, hogy míg egy bizonyos motiváló eszköz hatékonyan müködik az egyik országban, addig ugyanaz az eszköz teljességgel hatástalan egy másik államban (hovatovább még ronthatja is a dolgozók teljesítményét) (Juhász, 2014b, p. 58).

Számos kutató vizsgálta, hogy mi hajtja, mi „mozgatja" az embereket céljaik elérésében, vágyaik beteljesítésében. Kutatásaikból több elmélet is született. A legtöbb elmélet arra keresi a választ, hogy miért úgy viselkednek vagy cselekednek az emberek, ahogy éppen azt teszik? (Armstrong, 1991, p. 154 in Tóthné, 2012, p. 256). Az 1. táblázatban röviden áttekintem a kutatásban alkalmazott motivációs elméletek legfontosabb megállapításait.

A tanulmány az EFOP 3.6.1-16-2016-00001 „Kutatási kapacitások és szolgáltatások komplex fejlesztése az Eszterházy Károly Egyetemen” projekt keretén belül - a doktori fokozatszerzés megindításának támogatására kiírt pályázat támogatásával készült el. 
1. táblázat A kutatásban alkalmazott motivációs elméletek legfontosabb megállapításai

\begin{tabular}{|c|c|}
\hline $\begin{array}{r}\text { Motivá } \\
\text { megalkotó }\end{array}$ & Motivációs elmélet legfontosabb megállapításai \\
\hline $\begin{array}{l}\text { McClelland teljesítmény- } \\
\text { hatalom elmélete }\end{array}$ & $\begin{array}{l}\text { Három alapvető emberi szükséglet létezik: } \\
\text { 1. a teljesítmény elérésének szükséglete, } \\
\text { 2. a valahová tartozás iránti igény szükséglete, és } \\
\text { 3. a hatalom iránti igény szükséglete (Klein, 2001, p. 301). }\end{array}$ \\
\hline $\begin{array}{l}\text { Herzberg kéttényezós } \\
\text { szükségletelmélete }\end{array}$ & 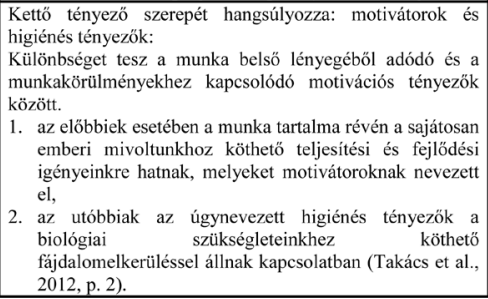 \\
\hline
\end{tabular}

Forrás: Klein (2001, p. 301), Takács et al. (2012, p. 2) alapján saját szerkesztés

A kutatás végzése során tehát McClelland teljesítményhatalom elméletén és Herzberg kéttényezős szükségletelméletén alapuló kérdöíveket használtuk fel. A választásom azért esett erre a két elméletre és a hozzájuk kapcsolódó kérdőívek használatára, mivel ezen elméletek a legkorábban kidolgozott motivációtartalom-elméletek közé sorolhatók - így létjogosultságuk megkérdőjelezhetetlen - továbbá ezekhez állt rendelkezésre magyar nyelvre adaptált kérdőív (lásd: Gyökér, 2006).

Az alábbiakban ezen elméletek legfontosabb megállapításait, kutatási eredményeit és kritikáit foglalom össze:

\section{McClelland véleménye szerint}

- a motívumok érzelmi felhangokkal rendelkező ismeretkészletek. Ezek valamely élményminőségek iránti preferencia vagy készenlét köré szerveződnek. Összesen három alapvető szükségletet különít el: a valahová tartozás iránti igény, a teljesítmény elérésének szükséglete és a hatalom szükséglete (Klein, 2001, p. 297-301).

- az elméletalkotó szerint mindhárom motiváló tényező minden emberben megvan. A három egymáshoz viszonyított aránya és erőssége azonban különböző az egyénekben (Radó \& Réthy, 2011, p. 143).

- az érzelmi élmények osztályaira vonatkozó viszszatérő preferenciák az implicit motívumok. Ezek azok, melyek McClelland meggyőződése szerint a motívumok lelkét alkotják (az „erősebbnek lenni” érzés a hatalommotívumban, a „,közel lenni” érzés az intimitásmotívumban, a ,jobban csinálni” érzés a teljesítménymotívumban központi jelentőségü).

- McClelland az alacsony affiliációs (valahová tartozás igénye, társas kapcsolatok igénye) szükséglettel és magas hatalomszükséglettel rendelkezö - valamint az utóbbi gátlására hajlamos - mintázatot gátolt hatalommotivációnak nevezte el (Carver \& Scheier, 2006, p. 123-127). A gátolt hatalommotivációval rendelkező személyek nagyon hatékonyak mások - az értékesítés során is nagy jelentőséggel bíró - meggyőzésében. Jellemzőjük, hogy másoknál sokkal gördülékenyebben tudnak beszélni, valamint hatékonyabban tudják olvasni a nonverbális jelzéseket (Schultheiss \& Brunstein, 2002, p. 575-576).

\section{Herzberg szerint,}

- ha az alacsonyabb szintü szükségletek kielégítésre kerülnek, az még nem vezet megelégedettségre, legfeljebb a munkával szembeni közömbös attitűd kialakulására; amennyiben az ilyen szükségletek nem kerülnek kielégítettségre, akkor az feltétlenül elégedetlenséghez vezet,

- a munkával való elégedettség alapvetően a magasabb rendű szükségletek kielégítettségétől függ; azonban, ha a magasabb rendü szükségletek nem elégülnek ki, akkor az nem vezet a munkával való elégedetlenségre, inkább csak a munkával szembeni semleges attitüd kialakulására.

- egészségtani (higiénés) tényezőknek nevezte el azokat a tényezőket, melyeknél a munkával való elégedetlenség a fizika környezettől, a munkatársaktól, a vezetőktől ered. Motivátoroknak nevezte el azokat a tényezőket, melyek esetében a megelégedettség a munka tartalmától, az érdekes, az ember képességeit próbára tevő munkatevékenységtől függ (Klein, 2001, p. 347).

- az értékesítők esetében felvetődik a kérdés: lehet-e őket pénzzel motiválni? Az elméletalkotó szerint motivációs szempontból nincs érdemi különbség a pozitív ösztönzők (pl. anyagi ösztönzés, pénz) és a negatív ösztönzők (pl. szervezeti szabályok, ellenőrzés) között. „Az anyagi ösztönzők felkínálásával csupán a pénzt felkínáló kerül motivált állapotba, ő szeretne bizonyos magatartást kiváltani, bizonyos eredményt elérni. A másik csak a pénz elnyerésére törekszik, s csupán ezért teszi meg azt, amit elvárnak töle. Motivációról azonban - Herzberg felfogása szerint - csak akkor beszélhetünk, ha az nem szorul állandó külső megerősítésre, hanem maga akar cselekedni, egyfajta „belső generátor” hajtja.” (Bakacsi, 2007, p. 90).

Herzberg szerint a munkavégzés során az emberek elvárásai a következők:

- higiénés tényezők: jó fizetés, biztonság, tekintély, munkakörülmény, panaszok meghallgatása, szabadidő eltöltési lehetőség, tanulási- és előmeneteli lehetőség,

- motivátorok: a munka általi elégedettség, a kihívás, amit a munka jelent, szellemi képesség kihasználása,

- higiénés tényezők és motivátorok is lehetnek egyben: a jó csapatszellem, jól informáltság (Roóz, 2001, p. 259).

A herzbergi modellt magyar vállalati kultúrán Takács és munkatársai vizsgálták. A mintegy 383 fős, zömében ügyfélszolgálati - a pénzügyi értékesítői területtel némiképp rokon - munkakörben alkalmazott munkavállalók mintáán végzett vizsgálatok a következő eredményeket hozták: „létezik egy „szürke zóna”, azaz olyan motivátortényezők, amelyeknek a hiánya elégedetlenséget okoz, és olyan higiénés tényezők, amelyek megléte elégedettséget.” Ez a zóna „,nem független az adott szervezeti valóságtól”, a rá „,fordított figyelem nélkül Herzberg tanainak a gyakorlatba való legprecízebb módon történő átülte- 
tését követően is felütheti a fejét az elégedetlenség a szervezeten belül, annak minden nem kívánatos következményével együtt”. Vannak továbbá olyan, úgynevezett „kétarcú” szükségletek, melyek „,bizonyos feltételek mentén higiénés tényezőként, más körülmények között pedig motivátortényezőként viselkednek... „E tényezők azonosítása és a hatásmechanizmusukat befolyásoló feltételek feltárása szintén szervezetspecifikus diagnózist kíván" (Takács et al., 2012, p. 16).

McClelland és Herzberg elméleteit számos kritika érte. Az alábbiakban a Bakacsi (2010, p. 63-65) által - McClelland (1965), továbbá Robbins \& Judge (1993, p. 191) alapján - öszszegzett kritikai észrevételek olvashatók:

McClelland elméletének

- „,...lényeges megállapítása az is, hogy ezek a motívumok nem örökletes jellegüek, hanem tanultak, s különböző társadalmakban, vagy a társadalmi fejlődés különböző szakaszaiban eltérő jellemzőket mutatnak.

- ...nem is tárgyalja az alapvető szükségleteket, lévén azok jó része velünk született, örökletes.

- ...nem feltételez továbbá hierarchikus alá-fölé rendeltséget, kielégülés-továbblépés jellegü kapcsolatot az egyes szükségletek között. Ezek a motivációk valamilyen mértékben mindenkit jellemeznek, de egyénileg nagyon eltérö arányokban."

Herzberg elméletéről elmondható, hogy

- „,..tulajdonképpen nem is motivációelmélet, hanem attitüdvizsgálat: csak a munkával való elégedettségre ad magyarázatot a maga érvényességi körén belül.

- ...nem fogalmazott meg átfogó elégedettségi mércét, így előfordulhatott az is, hogy valaki nem szereti munkájának egy részét, míg egészében elfogadhatónak tartja.

- ...eltekint attól, hogy a két tényező értelmezésbe független (környezeti) változókat is bekapcsoljon."

A fentebb bemutatott motivációs elméletek üzletkötők esetében történő alkalmazhatóságába a 2. táblázat nyújt betekintést, kiemelve az egyes elméletekhez kapcsolódó menedzseri magatartási formákat.

2. táblázat A kutatásban alkalmazott motivációs elméletek alkalmazhatósága

\begin{tabular}{|c|l|}
\hline Elmélet & \multicolumn{1}{|c|}{ Menedzseri alkalmazhatóság } \\
\hline $\begin{array}{c}\text { Herzberg higiéné-motivátor } \\
\text { elmélete }\end{array}$ & $\begin{array}{l}\text { Felismeri, hogy a fizetés és más higiénés tényezök - bár } \\
\text { fontosak az eladószemélyzet motiválásában - nem } \\
\text { elégségesek hosszú távon a magas motivációs szint } \\
\text { fenntartásában. }\end{array}$ \\
\hline $\begin{array}{c}\text { McClelland tanult } \\
\text { szükségletek elmélete }\end{array}$ & $\begin{array}{l}\text { Bizonyos esetekben érdemes növelni az eladószemélyzet } \\
\text { teljesitmény iránti igényét tréninggel vagy tanácsadással; } \\
\text { üzletkötők tanítása önkontrollra és érettségre, hogy ki } \\
\text { tudják egyensúlyozni a hatalom iránti igényüket tárgyalás } \\
\text { során. }\end{array}$ \\
\hline
\end{tabular}

Forrás: Ingram \& LaForge (1992, p. 396), Mitev (2008, p. 200)

Amennyiben az értékesítők sokaságát leszűkítjük a pénzügyi területen dolgozó üzletkötőkre, további érdekes ösztönzési eljárásokat és gyakorlatokat találunk. Az alábbi példából kiderül, hogy milyen figyelemre méltó módon motiválja dolgozóit az egyik legnagyobb amerikai bizto- sítótársaság az indianapolisi American United Life Insurance Company (AUL). A biztosítótársaság a juttatások olyan széles skáláját kínálja dolgozóinak, amely messze meghaladja a legtöbb versenytárs által nyújtott nyugdíjés egészségbiztosítási csomagot. A juttatások közül a legnépszerübb a cég épületében található úgynevezett egészségklub (egyfajta edzöterem). A vállalat fedezi a belépési díj felét, valamint az éves tagdíj több mint 50 százalékát is magára vállalja, így téve vonzóbbá az egészségklubba történő belépést alkalmazottai számára. Amennyiben fizetésemelést adna dolgozóinak, akkor „,csak” azt érné el, hogy anyagilag megengedhessék maguknak a tagságot, így viszont a vállalat képes lesz befolyásolni, hogy munkavállalói hogyan használják fel javadalmazási keretüket. Az AUL így jól jár, mivel az egészségklub szolgáltatásainak igénybevétele révén nagy valószínűséggel egészségesebb dolgozói lesznek, akik kevesebb időt fognak betegállományban tölteni (Shankle, 1992 in Lazear, 2006, p. 407).

A jólét-érzetet és ezzel összefüggésben a szervezet iránti elköteleződést Kun Ágota (2010, p. 40) szerint például a következő tényezőkkel lehet elérni: a munka-magánélet közti egyensúly, a munkával való elégedettség, jó munkahelyi kapcsolatok, erős munkamotiváció, felelősség és autonómia, a munka élvezete, stressz- és feszültségmentes munkahelyi légkör, nyílt kommunikáció, megfelelö munkavégzési feltételek, egyéni teljesítmény elismerése, visszajelzés, vezetői támogatás, dolgozó iránti tisztelet. Egy friss hazai nagymintás kutatás eredményei azonban arra hívják fel a figyelmet, hogy a szervezeteknek fel kell készülniük a munkavállalói elkötelezettség gyengülésére, amit a motivációs rendszer felülvizsgálatával és a dolgozói igényekhez igazításával tudnak mérsékelni (Kozák \& Krajcsák, 2018).

Egyes szerzők „,csupán” egyetlen motivációt, az én növelésére való törekvést, az ún. énkiterjesztést tartják a legfontosabb hajtóerőnek, melynek megnyilvánulási formái például a következők lehetnek: büszkeség, orgazmus, boldogság, öröm. Az énszükületé pedig például a félelem, a szorongás, az agresszió. A rendkívüli módon énkiterjesztett - ami leginkább a hofstedei értelemben vett individualista beállítottságú kultúrákra jellemző, ahol az énközpontúság, önállóság dominál (Borgulya \& Barakonyi, 2004, p. 137) - kultúrákban az emberek igyekeznek a problémákra fókuszálni és megoldani azokat. Ezzel szemben a túlzottan énszűkített kultúrákban a munkavállalók egy darabig nagyobb teljesítményt nyújtanak, de mindezt a vállalatoknak magasabb fizetésekkel kell kompenzálniuk. Jó példa erre - a pénzügy területén - a brókerházak esete: extrém énszükület mellett ugyanis hatalmas fizetéseket keresnek a brókerek (Fodor, 2010, p. 41-45).

Egy 1999-ben végzett és 2000-ben publikált az akkori magyar bankszektor, mintegy 90 \%-ára kiterjedő kérdőíves felmérés alapján az alkalmazottak motiválásában összesítve és fontossági sorrendben a következő tényezőknek tulajdonítottak jelentős szerepet a bankok (a második és a harmadik tényező sorrendje kisbankok körében felcserélödött):

1. bér és prémium (nagybank, középbank és kisbank esetében), 
2. egyéb nem bér jellegű juttatások (nagybank és középbank esetében),

3. karrierlehetőség felvázolása (nagybank és középbank esetében) (Zsámboki, 2000, p. 36).

Az Aon Legjobb Munkahelyek programban annak 2001-es hazai indítása óta, mintegy 2.000 vállalat mérettette meg magát, mintegy 410.000 munkavállaló visszajelzése alapján. A dolgozói elkötelezettség terén a legjobb munkahelyek az átlagostól a következő dimenziókban értek el kiemelkedő eredményt (ezek többsége motivációs tényezőnek is tekinthető): a feladatnak és felelősségi körnek megfelelö díjazás, a felső vezetés a vállalat legértékesebb erőforrásának tartja az alkalmazottakat, vonzó munkáltatói márka, lelkesítő jövőkép, egyértelmű irányok, szervezeti egységek közötti hatékony együttműködés. 2015-ben a cégeknek mintegy 93\%-a gondolta úgy, hogy az elkötelezettségnek az üzleti célok elérése szempontjából stratégiai szerepe lesz az elkövetkező időszakokban (Aon Magyarország, 2016, p. 5). 2014-ben a legjobb munkahelyek között kettő pénzügyi szolgáltató cég is szerepelt: a Fundamenta-Lakáskassza Zrt. a 250-1000 fő közötti vállalatok kategóriájában, és a Provident Pénzügyi Zrt. az 1000 fó feletti vállalatok kategóriájában (Aon Magyarország, 2014, p. 10). Világviszonylatban - több mint négy millió munkavállaló véleménye alapján - a vállalat iránti elkötelezettség terén a következő tényezőknek volt kiemelt szerepe: felhatalmazó környezet, munkavállalói értékajánlat (angolul: employee value proposition, mely egy a vállalat központi üzenetét közvetítő ajánlat (Kajos \& Bálint, 2014, p. 74)), jutalmak és elismerések, karrierlehetőségek, képzés-fejlesztés (Aon Hewitt, 2016, p. 4).

Egy 1.000 fös, nemre, korra, régióra és iskolai végzettségre nézve a magyar lakosságot reprezentatívan képviselő mintán végzett hazai kutatás szerint a magyar munkavállalókat a következő öt legfontosabb tényezővel lehet motiválni (fontosságuk sorrendjében):

- megfelelö munkahelyi légkör, bánásmód (akár cég-dolgozók, akár vezetők-beosztottak szempontjából),

- munkahely megtartásának biztonsága, jövője,

- versenyképes fizetés és anyagi juttatások,

- méltányos és igazságos díjazás,

- megfelelő munkatársi kapcsolatok, jó munkahelyi csapat (Farkas et al., 2013, p. 15-16).

Ugyanezen szerzők összefoglalták a korábban magyar munkavállalói mintán végzett kutatások aggregátumait (Farkas et al., 2013, p. 14). 1990-ig visszamenőleg, mintegy 49 kapcsolódó publikációt tekintettek át. Kutatási eredményeik szerint - egy három fokozatú skálán: nagyon fontos, fontos, semleges kategóriákkal - a következő motivációs tényezők kapták a leggyakrabban a nagyon fontos minősítést:

- karrierlehetőség, előrelépési lehetőségek a szervezeten/cégen belül,

- munkahely megtartásának biztonsága, jövője,

- rendszeres dolgozói tájékoztatás,

- munkatartalmi jellemzők: a végzett munka érdekes és értelmes.
Előfordulási gyakoriságukat tekintve pedig a következő tényezők kerültek az élre:

- versenyképes fizetés és anyagi juttatások,

- dolgozó által választható béren kívüli juttatások (cafeteria),

- karrierlehetőség, előrelépési lehetőségek a szervezeten / cégen belül,

- továbbképzés, szakmai fejlődés biztosítása,

- megfelelő munkatársi kapcsolatok, jó munkahelyi csapat.

Az elméleti és gyakorlati kutatási eredmények bemutatásának végén, mintegy összefoglalásként Mitev (2008, p. 200-201) igen pontos és találó irányelveit szeretném ismertetni. Véleménye szerint a következő tényezők megléte szolgálja leginkább az eladószemélyzet motiválását:

1. toborzás és kiválasztás: azon üzletkötők felkutatása és kiválasztása a munkaerőpiacról, akiknek személyes motívumai összhangban állnak a vállalatnak az értékesítőkkel szemben támasztott követelményeivel és nyújtott jutalmaival. (ez különösen azon értékesítési vezetők számára lényeges, akik kevéssé tudják módosítani a céges javadalmazási rendszereket és a munkadimenziókat),

2. egyéni igények figyelembevétele: azok beépítése a motivációs programba,

3. készségfejlesztés és információnyújtás: segítve az üzletkötők szocializációját, továbbá csökkentve a szerepekkel összefüggő problémákat,

4. munkakialakítás és újratervezés motivációs eszközként történő alkalmazása: törekedve például az autonómia, a sokféle készség és az állandó visszajelzés kialakítására,

5. önbecsülés felépítése a motiváció és a teljesítmény emelése érdekében: jó teljesítmény - pozitív viszszajelzés; elvárt teljesítmény hiánya - konstruktív problémamegoldás,

6.proaktív problémamegoldás a motiváció és a frusztráció terén: lehetőleg azok megjelenése előtt.

Az elméletekre épülő és a kutatásban alkalmazott kérdőívek Gyökér Irén (2006, p. 4-5) munkája alapján lettek felhasználva. A Motiváció - Mit várnak az emberek a munkájuktól? kérdöív (Lussier, 1993 in Gyökér, 2006, p. 4) esetében egy ötfokozatú Likert-skálán kellett a felsorolt munkával kapcsolatos tényezők közül eldöntenie a vizsgálati személynek, hogy az mennyire fontos számukra (az egyes a nem fontos, az ötös a nagyon fontos értéket képviselte). Az összesen 12 állítást tartalmazó kérdőív 6 higiénés tényezöt (pl. a jó fönök, a munka presztízse stb.) és 6 motivátort ( $\mathrm{pl}$. az érdekes munka, a munka elismerése stb.) mért. Így mind a higiénés tényezők, mind a motivátorok esetében maximálisan 30 pont volt elérhetö.

A Motiváció - Mi motiválja Önt? kérdöív (Steers \& Braunstein, 1976, p. 254.; Lussier, 1990, p. 120. in Gyökér, 2006, p. 5.) esetében szintén egy ötfokozatú Likert-skálán kellett eldöntenie a kérdőív kitöltőjének, hogy az adott állítás mennyire áll közel önmagához (az egyes a nem ért egyet, az ötös a teljesen egyetért kategóriát képviselte). Az összesen 15 állítást tartalmazó kérdőív 5 állítása a teljesítménnyel (pl. Szeretem a nehéz 
kihívásokat.), 5 állítása a hatalommal (pl. Szeretem, ha megbíznak valamivel.) és további 5 állítás a kapcsolattartással függ össze (pl. Szeretném, ha mások szeretnének.). Így mind a három esetében maximálisan 25 pont volt szerezhető kategóriánként.

A fenti szakirodalmi áttekintés alapján a következő hipotéziseket állítom a mintában szereplő értékesítőkröl:

H1:A mintában szereplő pénzügyi, biztosítási tevékenység nemzetgazdasági ág értékesítői - a herzbergi motivációs elméletén alapuló - higiénés tényezőkkel szemben a motivátorok segítségével ösztönözhetők nagyobb teljesítményre.

H2: A mintában szereplő pénzügyi, biztosítási tevékenység nemzetgazdasági ág értékesítői - a mcClellandi motivációs elméleten alapuló - hatalom és kapcsolattartás motívumokkal szemben a teljesítmény motívum révén ösztönözhetők nagyobb produktivitásra.

H3: Van - statisztikailag igazolható és erős - korrelációs kapcsolat a mintát alkotó értékesítők éves bruttó jövedelme és a motivációs kérdőívek tényezői (higiénés tényezők, motivátorok, teljesítmény, hatalom, kapcsolattartás) között.

H4: Léteznek olyan - a vizsgálatban használt motivációs kérdőívek által meghatározott - motivációs tényezők, melyek a pénzügyi, biztosítási tevékenység nemzetgazdasági ágban dolgozó értékesítők mintájának esetében előre jelzik/jelezhetik az egyes üzletkötők anyagi sikerességét.

\section{A kutatás módszertana: a vizsgálat alanyai, mérés, adatgyújtés, elemzés ${ }^{2}$}

\section{A vizsgálat alanyai}

A vizsgálat alanyai a felvétel időpontjában a pénzügyi, biztosítási tevékenység nemzetgazdasági ág területén, azon belül értékesítői munkakörben dolgozó munkavállalók. A bankoknál, biztosító társaságoknál, lakás-takarékpénztáraknál, pénzügyi tanácsadóknál, valamint faktorcégeknél, lízingcégeknél, takarékszövetkezeteknél és tőzsdei vállalatoknál dolgozó foglalkoztatottak alapsokaságából az ügyfelekkel közvetlenül, személyes kontaktusba kerülő értékesítők kerültek a kutatás középpontjába.

\section{Mérés, adatgyüjtés}

A mérés során zárt és nyitott kérdésekböl álló kérdőív került kitöltetésre a vizsgálati személyekkel. A vizsgálati alanyok online, az internet segítségével töltötték ki a kérdőíveket.

Az adatgyüjtés legfontosabb ismérvei:

- A kérdőív online módon 2016. december 14. és 2017. július 20. között volt elérhető és kitölthető.

- A mintavétel a nem véletlen mintavételi eljárások közül, a hólabda-mintavételi eljárással történt.

- Az adatfelvétel során megkeresésre kerültek olyan nagyobb, a pénzügyi, biztosítási tevékenység nemzetgazdasági ághoz kapcsolódó szervezetek és azok tagjai közvetlen vagy közvetett formában, mint a Magyar Bankszövetség, a Magyar Biztosítók Szö- vetsége, az Országos Takarékszövetkezeti Szövetség, a Pénzügyi Vállalkozások Országos Egyesülete, a Magyar Lízingszövetség, a Magyar Kereskedelmi és Iparkamara, a Magyar Közgazdasági Társaság.

- 1.000 fö eredményei kerültek bele a véglegesített mintába.

- A munkahelyek nemzetgazdasági ágazatok szerinti megoszlása alapján a legtöbb vizsgálati személy bankban dolgozik (1. ábra), ezt követik a biztosítók, majd a lakás-takarékpénztárak és a pénzügyi tanácsadói irodák munkatársai. A tőzsde, lízing, faktoring és takarékszövetkezeti üzletágak képviselői elenyésző arányban töltötték ki a kérdőívet (a négy terület összesen 5,3\%-át teszi ki a mintának).

\section{1. ábra A válaszadók munkahelyének nemzetgazdasági} ágazatok szerinti csoportosítása (fő)

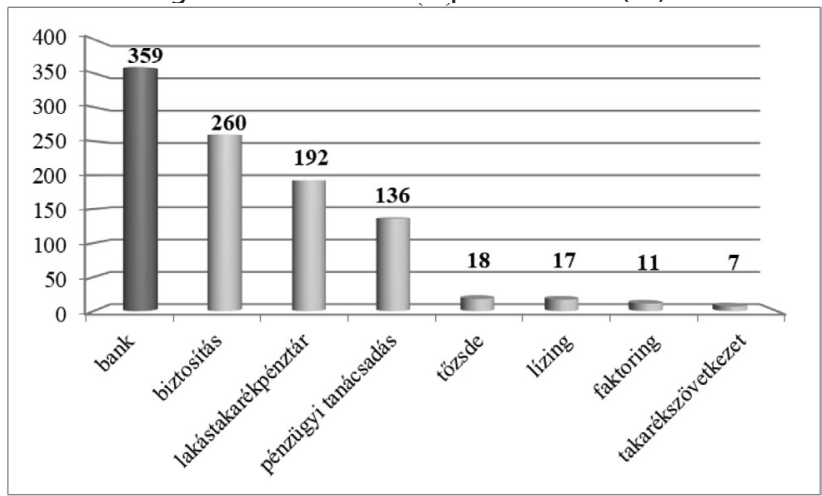

Forrás: saját kutatás alapján, saját szerkesztés, 2019

- Reprezentativitás: a Központi Statisztikai Hivatal (2016) szakstatisztikusától - egyedileg kért és - kapott, a 2011. év népszámlálási adatbázisára vonatkozó lekérdezése alapján a vizsgált nemzetgazdasági ágra vonatkozóan a következő megállapítás tehető. FEOR-szám szerint a kutatáshoz kapcsolódó négy foglalkoztatási típusban összesen 69160 fö dolgozott 2011-ben, akiknek 3,47\%-a Tözsde- és pénzügyi ügynökként vagy brókerként (FEOR szám: 3613) volt alkalmazva. 20,07\%-a Biztosítási ügyintézőként vagy ügynökként (FEOR szám: 3621), 34,36\%-a Pénzintézeti ügyintézőként (FEOR szám: 3612), végezetül 42,11\%-a Ügynökként (a biztosítási ügynök kivételével, FEOR szám: 3624) volt foglalkoztatva. Mivel a Központi Statisztikai Hivatal ettől részletesebb adatokat nem publikál és így a különböző szempontokból történő reprezentativitás vizsgálatára sincs lehetőség, ezért az eredmények általánosíthatósága korlátozott.

\section{Elemzés}

A begyüjtött adatok elemzése és kiértékelése az Excel és az SPSS-programok segítségével történt.

\footnotetext{
${ }^{2}$ A kutatás egy - várhatóan 2019-ben védésre kerülő - doktori értekezéshez kapcsolódó felmérés keretén belül került lebonyolításra, melynek módszertana szükségszerűen megegyezik jelen tanulmány módszertanával.
} 


\section{Eredmények a motivációs kérdőívek alapján}

A Motiváció - Mit várnak az emberek a munkájuktól? kérdőív kérdéseire adott válaszok eredményei alapján (2. ábra) mind a herzbergi higiénés, mind pedig a motivátortényezők esetében a legmagasabb átlagértéket a lakás-takarékpénztárak munkatársai érték el. Legalacsonyabb pontokat pedig a tőzsdei alkalmazottak adtak, mindkettő kategóriában. Meglepő módon nem a motivátoroknak lett nagyobb szerepe, hanem az olyan higiénés tényezőknek, mint például a jó fizetés, a biztonság, a tekintély, a munkakörülmények esetleg a tanulási, előmeneteli lehetőségek (H1 hipotézis elvetése). Ez az eredmény a fentiekben már bemutatott, Farkas és munkatársai által publikált (2013) kutatás eredményeivel van összhangban. Az eredmények szórása terén a higiénés tényezők esetében a legnagyobb szórás a faktorcégek, a legkisebb a takarékszövetkezetek üzletkötőinél volt tapasztalható. Míg a motivátorok esetében a legmagasabb szórás a tőzsdei cégek, addig a legalacsonyabb szintén a takarékszövetkezetek értékesítőinél fordult elő (3. táblázat). (Nagy valószínüséggel ezek a kiugró értékek az adott ágazatok alacsony elemszámainak is köszönhetők.)

2. ábra A válaszadók higiénés és motivátortényezőkre adott pontátlagai, ágazatokra vetítve (pont)

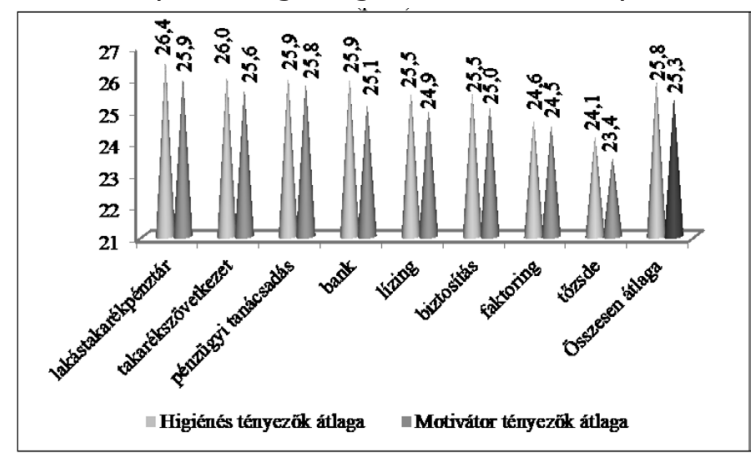

Forrás: saját kutatás alapján, saját szerkesztés, 2019

3. táblázat A Motiváció - Mit várnak az emberek a munkájuktól? kérdőívben elért átlageredmények, elemszámok és szórások, ágazatonként és összesen

\begin{tabular}{|c|c|c|c|}
\hline \multicolumn{4}{|c|}{ Report } \\
\hline \multicolumn{2}{|c|}{$\begin{array}{l}\text { q13 Kérem adja meg a pénzuigyi szféra melyik } \\
\text { területén dolgozik! Több érintett terület esetén a } \\
\text { relevánsabbat jelölje meg! }\end{array}$} & $\begin{array}{l}q^{82} \\
\text { Higiénés } \\
\text { tényezök }\end{array}$ & $\begin{array}{c}\mathrm{q} 83 \\
\text { Motivátorok }\end{array}$ \\
\hline \multirow[t]{3}{*}{ (2) } & Mean / Átlag & 25,88 & 25,09 \\
\hline & N / Elemszám & 359 & 359 \\
\hline & Std. Deviation / Szórás & 3,439 & 3,470 \\
\hline \multirow{3}{*}{ biztositás } & Mean $/$ Átlag & 25,45 & 25,02 \\
\hline & $\mathrm{N} /$ Elemszám & 260 & 260 \\
\hline & Std. Deviation / Szórás & 3,499 & 3,278 \\
\hline \multirow{3}{*}{ lakás-takarékpénztár } & Mean $/$ Átlag & 26,44 & 25,91 \\
\hline & $\mathrm{N} /$ Elemszám & 192 & 192 \\
\hline & Std. Deviation / Szórás & 2,868 & 3,367 \\
\hline \multirow{3}{*}{ pénzügyi tanácsadás } & Mean / Átlag & 25,95 & 25,76 \\
\hline & $\mathrm{N} /$ Elemszám & 136 & 136 \\
\hline & Std. Deviation / Szórás & 3,882 & 4,040 \\
\hline \multirow{3}{*}{ tözsde } & Mean/Átlag & 24,11 & 23,44 \\
\hline & $\mathrm{N} /$ Elemszám & 18 & 18 \\
\hline & Std. Deviation / Szórás & 3,579 & 4,743 \\
\hline \multirow{3}{*}{ lízing } & Mean / Átlag & 25,47 & 24,94 \\
\hline & $\mathrm{N} /$ Elemszám & 17 & 17 \\
\hline & Std. Deviation / Szórás & 3,145 & 3,363 \\
\hline \multirow{3}{*}{ faktoring } & Mean / Átlag & 24,64 & 24,45 \\
\hline & N/Elemszám & 11 & 11 \\
\hline & Std. Deviation / Szórás & 4,178 & 4,204 \\
\hline \multirow{3}{*}{ takarékszövetkezet } & Mean/Átlag & 26,00 & 25,57 \\
\hline & N/ Elemszám & & \\
\hline & Std. Deviation / Szórás & 1,915 & 2,637 \\
\hline \multirow{3}{*}{ Total/Összesen } & Mean /Átlag & 25,83 & 25,29 \\
\hline & N/Elemszám & 1000 & 1000 \\
\hline & Std. Deviation / Szórás & 3,432 & 3,531 \\
\hline
\end{tabular}

Forrás: saját szerkesztés az SPSS-program segítségével, 2019
A Motiváció - Mi motiválja Önt? kérdőív kérdéseire adott válaszok alapján a három mcClellandi motivációra (teljesítmény, kapcsolattartás, hatalom) adható maximális pontszámot (25 pont) egyik ágazat munkatársainak átlageredményei sem közelítették meg (3. ábra). A legnagyobb átlageredményt - egyedüliként meghaladva a 21 pontos értéket - a lakás-takarékpénztárakban dolgozók nyújtottak a teljesítmény motiváció esetében $(21,2)$. A kapcsolattartás motívumának terén a legjobban a pénzügyi tanácsadók és a lízingcégnél dolgozók teljesítettek (19,4 - 19,4), míg a hatalom terén a tőzsdei dolgozók eredménye kiemelkedő (18,7 pont) a többi ágazat eredményeihez képest. Az összes ágazat átlagát figyelembe véve a várakozásoknak megfelelően a teljesítmény motívum érte el a legnagyobb pontértéket (20,6), majd ezt követi a kapcsolattartás $(18,8)$ és végezetül a hatalom $(18,0)$ motiváció (H2 hipotézis elfogadása).

McClelland tanult szükségletek elmélete alapján a mintában szereplö értékesítők legfontosabb motívuma a teljesítmény, melyet a következő - már korábban is említett - módon lehet még magasabb szintre fejleszteni: az értékesítők teljesítmény elérése iránti igényét tanácsadással, tréninggel, esetleg önkontrollra való tanítással kívánatos növelni, annak érdekében, hogy így ki tudják egyensúlyozni a hatalom iránti igényüket az üzleti tárgyalások során (Ingram \& LaForge, 1992, p. 396; Mitev, 2008, p. 200).

Az eredmények szórása terén a teljesítménymotiváció esetében a legnagyobb szórás a faktorcégek, míg a legkisebb a takarékszövetkezetek üzletkötőinél volt tapasztalható (4. táblázat). A hatalommotivációnál a legmagasabb szórás a pénzügyi tanácsadással foglalkozó cégek, a legalacsonyabb a takarékszövetkezetek értékesítőinél fordult elő. Végezetül a kapcsolattartás motiváció esetében a legnagyobb szórás a faktorcégek, míg a legkisebb a takarékszövetkezetek üzletkötöinél volt tapasztalható (a teljesítménymotivációhoz hasonlóan). (A kiugró értékek többsége - nagy valószínűséggel ez esetben is - az adott szférák alacsony elemszámainak voltak köszönhetők.)

3. ábra A válaszadók teljesítmény-, kapcsolattartás- és hatalommotivációkra adott pontátlagai, ágazatokra vetítve (pont)

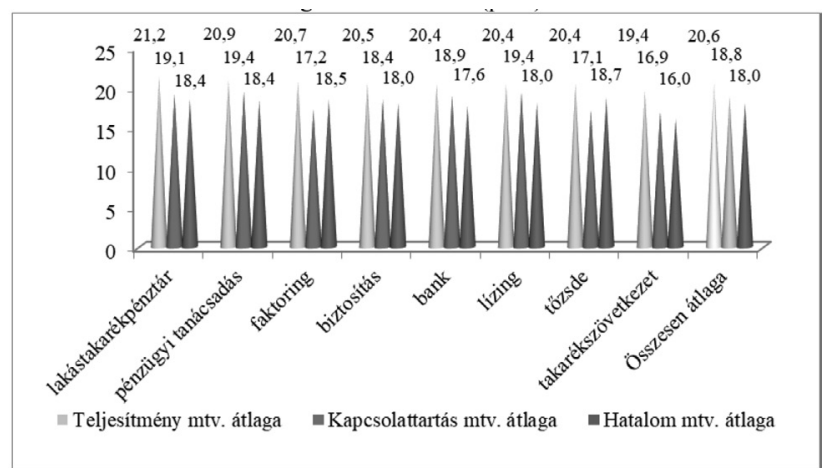

Forrás: saját kutatás alapján, saját szerkesztés, 2019 
4. táblázat A Motiváció - Mi motiválja Önt? kérdőívben elért átlageredmények, elemszámok és szórások, ágazatonként és összesen

\begin{tabular}{|c|c|c|c|c|}
\hline \multicolumn{5}{|c|}{ Report } \\
\hline \multicolumn{2}{|c|}{$\begin{array}{l}\text { q13 Kérem adja meg a pénzügyi szféra melyik } \\
\text { területén dolgozik! Több érintett terület esetén a } \\
\text { relevánsabbat jelölje meg! }\end{array}$} & $\begin{array}{c}\text { q84 } \\
\text { Teljesítmény }\end{array}$ & $\begin{array}{c}\mathrm{q} 85 \\
\text { Hatalom }\end{array}$ & $\begin{array}{c}\mathrm{q} 86 \\
\text { Kapcsolattartás }\end{array}$ \\
\hline \multirow{3}{*}{ bank } & Mean / Átlag & 20,42 & 17,64 & 18,93 \\
\hline & N/ Elemszám & 359 & 359 & 359 \\
\hline & Std. Deviation / Szórás & 3,051 & 3,842 & 3,702 \\
\hline \multirow{3}{*}{ biztositás } & Mean / Átlag & 20,49 & 17,99 & 18,39 \\
\hline & N/ Elemszám & 260 & 260 & 260 \\
\hline & Std. Deviation / Szórás & 2,839 & 3,528 & 3,735 \\
\hline \multirow{3}{*}{ lakás-takarékpénztár } & Mean / Átlag & 21,20 & 18,40 & 19,14 \\
\hline & N/ Elemszám & 192 & 192 & 192 \\
\hline & Std. Deviation / Szórás & 2,965 & 3,420 & 3,249 \\
\hline \multirow{3}{*}{ pénzügyi tanácsadás } & Mean / Átlag & 20,88 & 18,38 & 19,44 \\
\hline & N/ Elemszám & 136 & 136 & 136 \\
\hline & Std. Deviation / Szórás & 3,476 & 4,086 & 4,107 \\
\hline \multirow{3}{*}{ tözsde } & Mean / Átlag & 20,39 & 18,67 & 17,11 \\
\hline & N/ Elemszám & 18 & 18 & 18 \\
\hline & Std. Deviation / Szórás & 3,837 & 2,449 & 2,698 \\
\hline \multirow{3}{*}{ lízing } & Mean / Átlag & 20,41 & 18,00 & 19,35 \\
\hline & N/Elemszám & 17 & 17 & 17 \\
\hline & Std. Deviation / Szórás & 3,743 & 3,391 & 3,481 \\
\hline \multirow{3}{*}{ faktoring } & Mean / Átlag & 20,73 & 18,45 & 17,18 \\
\hline & N/Elemszám & 11 & 11 & 11 \\
\hline & Std. Deviation / Szórás & 3,849 & 3,908 & 4,309 \\
\hline \multirow{3}{*}{ takarékszövetkezet } & Mean / Átlag & 19,43 & 16,00 & 16,86 \\
\hline & N/ Elemszám & 7 & 7 & \\
\hline & Std. Deviation / Szórás & 1,718 & 1,732 & 1,345 \\
\hline \multirow{3}{*}{ Total / Összesen } & Mean / Átlag & 20,65 & 18,00 & 18,84 \\
\hline & $\mathrm{N} /$ Elemszám & 1000 & 1000 & 1000 \\
\hline & Std. Deviation / Szórás & 3,079 & 3,688 & 3,685 \\
\hline
\end{tabular}

Forrás: saját szerkesztés az SPSS-program segítségével, 2019

A mintát alkotó üzletkötők éves bruttó jövedelmük szerinti kategorizálása szerint (4. ábra) a válaszadók közül legtöbben (236 fö) 2 és 2,9 millió forint között keresnek. A második legnépesebb kategóriák esetében egyaránt 183 - 183 fó fizetése esik az 1 - 1,9 valamint a 3 - 3,9 millió forint közötti intervallumokba. Egymillió forintnál kevesebb összeget 66 fó, míg 10 millió forintnál többet összesen 33 fö keres évente. Egyetlen egy fö adott a kérdésnél értelmezhetetlen (,változó” megnevezésű) választ. Az üzletkötők éves bruttó fizetésének átlaga: 4,48 millió forint.

4. ábra A válaszadók éves bruttó jövedelme szerinti csoportosítása (millió forint)

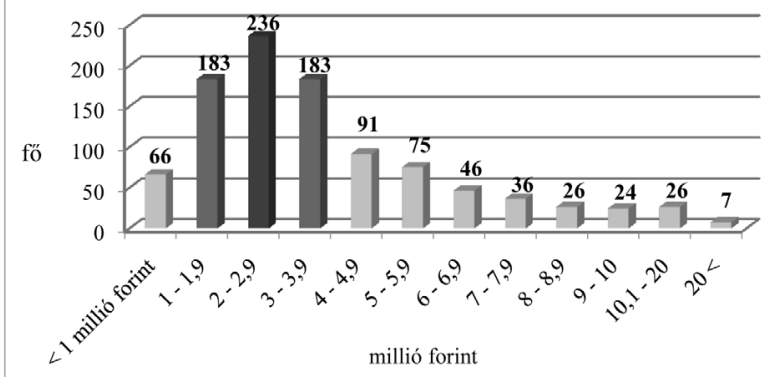

Forrás: saját kutatás alapján, saját szerkesztés, 2019

Felvetődik a kérdés (H3 hipotézis), hogy vajon van-e kapcsolat a motivációs kérdőívek által vizsgált tényezők és a mintát alkotó értékesítők tényleges - forintban mérhető - teljesítménye között? Jelen esetben a teljesítmény mérésére az éves bruttó jövedelem szolgál, feltételezve azt, hogy a jobb teljesítményt elérő üzletkötők jobban is keresnek. A hipotézis elfogadása, illetve elvetése többváltozós regresszióelemzéssel vizsgálható. A többváltozós regressziószámítás előfeltétele, hogy a függő változó (azaz az éves bruttó jövedelem) és a független változók, azaz a moti- vációs kérdőívek tényezői (higiénés tényezők, motivátorok, teljesítmény, hatalom, kapcsolattartás) között van-e és ha igen, akkor milyen erősségü ( 0,7 vagy a feletti az elvárt) a kapcsolat? További feltétel, hogy a független változók között gyenge kapcsolat legyen, azaz multikollinearitásról ne lehessen esetükben beszélni.

Az előfeltételek vizsgálatára szolgáló korrelációs mátrix (5. táblázat) eredményei alapján van - de közel sem számottevő - korrelációs kapcsolat az értékesítők tényleges teljesítménye (jelen esetben éves bruttó jövedelmük) és az egyes motivációs tényezők között (H3 hipotézis részbeni elfogadása). Mivel a multikollinearitást sem lehet kizárni - ugyanis van közepes vagy annál erősebb kapcsolat a független változók között ezért az előfeltételek teljesülésének hiánya miatt a többváltozós regressziós modell további eredményeiből statisztikailag releváns következtetéseket nem lehet levonni. A táblázat adataiból azonban megállapítható, hogy erôs pozitív korreláció van a higiénés tényezők és a motivátorok között $(0,725)$, továbbá közepes pozitív korrelációs kapcsolat áll fenn a higiénés tényezők és a teljesítmény, mint motivációs tényező között $(0,538)$. Ezen vizsgálati eredmények arra engednek következtetni, hogy a herzbergi higiénés tényezőknek - a H1 hipotézis elvetésével összhangban - és a mcClellandi teljesítménytényezőnek - H2 hipotézis elfogadásával összhangban - adekvát ösztönzőknek kell jelentősebb szerepet szánni ezen értékesítők motiválásában.

5. táblázat Az éves bruttó jövedelem és a vizsgált motivációs tényezők korrelációs mátrixa $(N=1000)$

\begin{tabular}{|c|c|c|c|c|c|c|c|}
\hline & & $\begin{array}{c}\text { q23.4 Kérem adja } \\
\text { meg teljes éves } \\
\text { bruttójövedelmét } \\
\text { milliö forintban! }\end{array}$ & $\begin{array}{c}\text { q82 } \\
\text { Higiénés } \\
\text { tényezök }\end{array}$ & $\begin{array}{c}q^{83} \\
\text { Motivatorok }\end{array}$ & $\begin{array}{c}\mathbf{q}^{84} \\
\text { Teljesítmény }\end{array}$ & $\begin{array}{c}9^{95} \\
\text { Hatalom }\end{array}$ & $\begin{array}{c}986 \\
\text { Kapcsolattartás }\end{array}$ \\
\hline \multirow{6}{*}{ 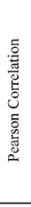 } & $\begin{array}{l}\text { q23.4 Kérem adja meg teljes } \\
\text { éves bruttó jövedelmét millió } \\
\text { forintban! }\end{array}$ & 1,000 & -059 & -013 & ,023 & ,073 &,- 031 \\
\hline & g82 Higiénés tényezök & -059 & 1,000 &, 725 & .538 & .356 & .396 \\
\hline & 983 Motivátorok & -013 & .725 & 1,000 & .668 & .512 & \\
\hline & g84 Teljesitmény & .023 & .538 & .668 & 1.000 & .603 & 450 \\
\hline & 985 Hatalom & .073 & .356 & .512 & .603 & 1.000 & .448 \\
\hline & 986 Kapcsolattartás & -.031 & .396 & .396 & .450 & .448 & 1.000 \\
\hline \multirow{6}{*}{ 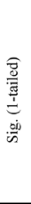 } & $\begin{array}{l}\text { q23.4 Kérem adja meg teljes } \\
\text { éves bruttó jövedelmét millióo } \\
\text { forintban! }\end{array}$ & & . 031 &, 343 & .238 & 011 & 167 \\
\hline & q82 Higiénés tényezök & .031 & & .000 & .000 & .000 & .000 \\
\hline & 983 Motivátorok &, 343 & ,000 & &, 000 &, 000 & .000 \\
\hline & q84 Te jesitmény & .238 & .000 & .000 & & .000 & ,00 \\
\hline & 985 Hatalom & .011 & 000 & .000 & .000 & & \\
\hline & 986 Kapcsolattartás & .167 & .000 & .000 & .000 & .000 & \\
\hline
\end{tabular}

Forrás: saját szerkesztés az SPSS-program segítségével, 2019

A pénzügyi, biztosítási tevékenység nemzetgazdasági ág területén minden a pénzröl szól, a szó szoros és annak átvitt értelmében, melyből adódóan a következő kérdés vetődik fel: léteznek-e olyan, a kutatásban használt kérdőívek által meghatározott motivációs tényezők, melyek a pénzügyi, biztosítási tevékenység nemzetgazdasági ágban dolgozó és a mintát alkotó értékesítők esetében előrejelezhetik az üzletkötők anyagi sikerességét?

A kérdések megválaszolására a kétváltozós logisztikus regresszióelemzést hívtam segítségül. A függő változó ebben az esetben bináris, azaz két kimenete lehetséges: az ötmillió forint feletti és az ötmillió forint alatti éves bruttó jövedelemmel rendelkező üzletkötők csoportja. A Központi Statisztikai Hivatal (2019) által publikált a vizsgált nemzetgazdasági ág 2018. évre vonatkozó 608 ezer forintos havi bruttó átlagkereset és a kutatás során rendelkezésre álló adatok, továbbá a kategorizálási próbák alapján ez az ötmillió forintos értékhatár tünt annak az összegnek, amely felett kereső értékesítők már 
"sikeresnek" mondhatják magukat. Legalábbis anyagi téren. Talán indokoltabb lett volna ebben az esetben a rendelkezésre álló módszerek közül a diszkriminanciaelemzést alkalmazni, de ott nem - még több kategorizálás után sem - sikerült nagyjából azonosnak mondható csoportnagyságokat létrehozni a keresetek függvényében. Mivel a diszkriminanciaelemzés meglehetősen robosztus a feltételek teljesülését illetően (Sajtos \& Mitev, 2007, p. 332-336) - a multikollinearitás ellenére - így a feltételek tekintetében megengedőbb módszert a kétváltozós logisztikus regressziót választottam.)

Az elemzésben összesen 999 üzletkötő adatait sikerült bevonni, mivel egy üzletkötő a nem számszerüsíthető „változó” megnevezést adta meg az éves bruttó keresetére rákérdező pontban. A kutatás alapjául szolgáló minta ötmillió forint alatt és felett kereső üzletkötőinek megoszlását a klasszifikációs táblázat (6. táblázat) mutatja be. Ötmillió forint alatt keres évente a minta 76 százaléka, ötmillió forint felett pedig a minta 24 százaléka. A táblázat 76 százaléka arra utal, hogy ha véletlenszerüen tippelnénk arra, hogy egy mintabeli üzletkötő ötmillió forint alatt keres, akkor 76 százalékban lenne igazunk (Sajtos \& Mitev, 2007, p. 356.).

\section{6. táblázat A minta 5 millió forint alatt és felett kereső} üzletkötőinek megoszlásának klasszifikációs táblázata a logisztikus regresszió elvégzése előtt

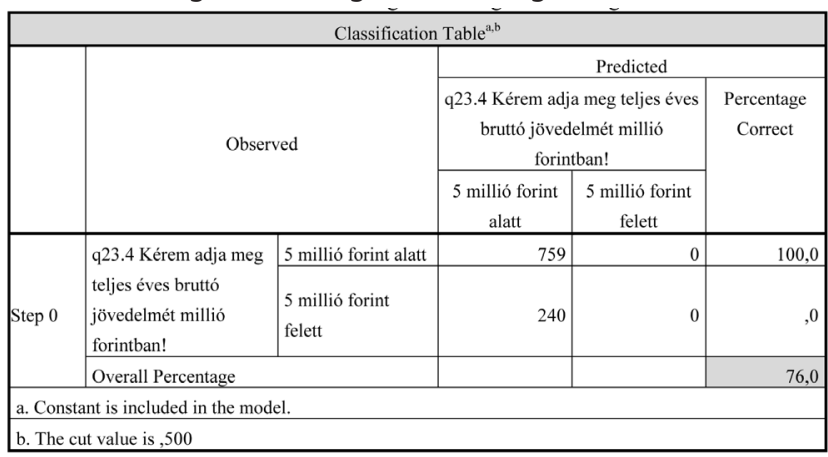

Forrás: saját szerkesztés az SPSS-program segítségével, 2019

A Wald-statisztika paraméterbecslésének eredménye alapján az eredmény szignifikáns. A független változók egyedi hatásának szignifikanciaszintje alapján pedig a lehetséges öt motivációs tényező közül a teljesítmény és a hatalom szignifikáns. A 7. táblázat az 5 motivációs tényezőt (mint független változót) tartalmazó modell szignifikanciaszintjét mutatja be, mely alapján a modell szignifikáns.

7. táblázat Az 5 motivációs tényezőt (mint független változókat) tartalmazó modell szignifikanciaszintje

\begin{tabular}{|c|c|c|c|c|}
\hline \multicolumn{5}{|c|}{ Omnibus Tests of Model Coefficients } \\
\hline \multirow{2}{*}{ Step 1 } & Step & 23,790 & 5 &, 000 \\
\cline { 2 - 5 } & Block & 23,790 & 5 &, 000 \\
\cline { 2 - 5 } & Model & 23,790 & 5 &, 000 \\
\hline
\end{tabular}

Forrás: saját szerkesztés az SPSS-program segítségével, 2019
Az 5 motivációs tényező (mint független változó) kombinációjának hatása a függő változóra kettő mutatószámmal is kiszámításra került (8. táblázat). A Cox \& Snell R négyzet mutató alapján az 5 változó - a meglehetősen csekély - 2,4 százalékot, míg a Nagelkerke $\mathrm{R}$ négyzet mutató alapján 3,5 százalékot magyaráznak. „A Nagelkerke R négyzet a Cox \& Snell mutató módosított változata, és mivel ez utóbbi mindig alulbecsli a valós értéket, a Nagelkerke-féle mutatóra érdemes hagyatkozni" (Sajtos \& Mitev, 2007, p. 356-357).

8. táblázat Az 5 motivációs tényező (mint független változó) kombinációjának hatása a függő változóra

\begin{tabular}{|c|c|c|c|}
\hline \multicolumn{5}{|c|}{ Model Summary } \\
\hline Step & $\begin{array}{c}-2 \text { Log } \\
\text { likelihood }\end{array}$ & $\begin{array}{c}\text { Cox \& Snell R } \\
\text { Square }\end{array}$ & $\begin{array}{c}\text { Nagelkerke R } \\
\text { Square }\end{array}$ \\
\hline 1 & $1077,820^{\mathrm{a}}$ &, 024 &, 035 \\
\hline $\begin{array}{l}\text { a. Estimation terminated at iteration number } \\
\text { parameter estimates changed by less than ,001. }\end{array}$ \\
\hline
\end{tabular}

Forrás: saját szerkesztés az SPSS-program segítségével, 2019

A minta ötmillió forint alatt és felett kereső üzletkötőinek megoszlásának klasszifikációs táblázata (9. táblázat) alapján, a logisztikus regresszió elvégzése után megállapítható, hogy a modell által helyesen kategorizált esetek aránya 75,9 százalék. A véletlen kategorizálás várható sikeréhez $(76 \%)$ viszonyítva ez azt jelenti, hogy 0,1 százalékkal segítik kevésbé jobban a független változók a függő változók helyes kategorizálását a véletlen kategorizálástól.

9. táblázat A minta 5 millió forint alatt és felett kereső üzletkötőinek megoszlásának klasszifikációs táblázata a logisztikus regresszió elvégzése után

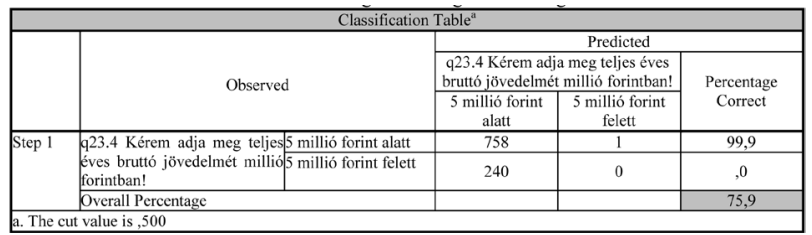

Forrás: saját szerkesztés az SPSS program segítségével, 2019

Az öt motivációs tényező együttes hatásának bemutatására - az ötmillió forint felett és alatt kereső üzletkötők kategorizálásában - a 10. táblázat szolgál. A táblázat azt hivatott bemutatni, hogy a Wald-statisztika alapján (,amely a béta (B) és a standard hiba hányadosának négyzete") az egyes motivációs tényezők mennyiben járulnak hozzá a modellhez, amennyiben a Wald-statisztika szignifikáns eredményt hozott az egyes motivációs tényezők esetében. Szignifikáns eredmény egyedül a hatalom, mint motivációs tényező esetében került kimutatásra. ,Az $\operatorname{Exp}(\mathrm{B}) \mathrm{a}$ táblázat legfontosabb mutatója, ugyanis ez mutatja meg, hogy az egyes értékek mennyivel javítják a becslést." Jelen esetben a hatalom 1,078-as értéke azt jelenti, hogy a hatalom motivációs tényező 7,8 százalékkal javítaná az esélyét annak, hogy helyesen lehessen kategorizálni az adott értékesítőt abból a szempontból, hogy ötmillió forint felett vagy az alatt keres (Sajtos \& Mitev, 2007, p. 359). Azaz ezen motivációs tényező esetében elért magasabb 
értékek utalhatnak arra, hogy az adott üzletkötő jobban keres, illetve jobban fog keresni a későbbiekben. Belátható, hogy ez meglehetősen csekély eredmény és csak egyetlen egy motivációs tényező esetében áll fenn (H4 hipotézis részbeni elfogadása).

10. táblázat A motivációs tényezőkön elvégzett kétváltozós logisztikus regresszió Wald-statisztikájának eredményei

\begin{tabular}{|c|c|c|c|c|c|c|c|c|c|}
\hline \multicolumn{10}{|c|}{ Variables in the Equation } \\
\hline & & \multirow[b]{2}{*}{ B } & \multirow[b]{2}{*}{ S.E. } & \multirow[b]{2}{*}{ Wald } & \multirow[b]{2}{*}{ df } & \multirow[b]{2}{*}{ Sig. } & \multirow[b]{2}{*}{$\operatorname{Exp}(B)$} & \multicolumn{2}{|c|}{$95 \%$ C.I.for EXP(B) } \\
\hline & & & & & & & & Lower & Upper \\
\hline \multirow[t]{6}{*}{ Step 1 $1^{a}$} & Higiénés tényezők &,- 045 &, 033 & 1,816 & 1 &, 178 & 956 & 896 & 1,021 \\
\hline & Motivátorok & ,013 &, 037 & ,117 & 1 &, 733 & 1,013 & ,942 & 1,085 \\
\hline & Teljesitmény & ,073 &, 038 & 3,648 & 1 &, 056 & 1,075 & ,998 & 1,158 \\
\hline & 985Hatalom & ,075 & ,028 & 7,286 & 1 & ,007 & 1,078 & 1,021 & 1,138 \\
\hline & Kapcsolattartás &,- 047 &, 024 & 3,945 & 1 & ,047 & ,954 & ,911 &, 995 \\
\hline & Constant & $-2,305$ & ,661 & 12,155 & 1 & ,000 & , 100 & & \\
\hline
\end{tabular}

Forrás: saját szerkesztés az SPSS-program segítségével, 2019

\section{Következtetések, jövőbeni kutatási javaslatok}

A fenti szakirodalmi összegzés és a vizsgált mintának a motivációs kérdőívekben elért eredményein végzett elemzések alapján megállapítható, hogy a pénzügyi, biztosítási tevékenység nemzetgazdasági ágban dolgozó, mintegy 1.000 fó értékesítő számára a herzbergi higiénés tényezők jelentenek nagyobb ösztönző erőt a motivátorokkal szemben. Ezen értékesítők motiválásában tehát az olyan higiénés tényezőknek kell, hogy nagyobb szerep jusson, mint például a munka biztonsága, a tekintély, a munkakörülmények javítása, esetleg a tanulási, előmeneteli alternatívák tárházának bővítése.

Megállapítható továbbá az is, hogy a vizsgált minta esetében az elért eredmények alapján a mcClellandi teljesítmény jelenti a legnagyobb serkentő tényezőt a kapcsolattartás és a hatalom motivációkkal szemben. Még nagyobb szerephez kell jutnia tehát esetükben a teljesítmény olyan típusú elismerésének, mint például a magasabb fizetés, vállalati béren kívül juttatások palettájának bővítése, vállalati presztízs utazások (külföldi nyaralások), mint „jutalmak” alkalmazása.

A kutatási eredmények azt is igazolták, hogy a vizsgált, pénzügyi területen dolgozó üzletkötők mintájának esetében közel sincs számottevő kapcsolat az értékesítők tényleges - forintosított - teljesítménye és a vizsgált motivációs tényezők között, illetve jelentős mértékben nem javítható az egyes üzletkötők jövedelem szerinti kategorizálása - valamint jövőbeni teljesítményük előrejelzése - a vizsgált motivációs tényezőket figyelembe véve (csupán csekély mértékben a hatalom motivációs tényező terén).

Jövőbeni kutatási irányokat vethet fel az a kérdés, hogy motiválhatóság szempontjából - mennyire átjárható az egyes ágazatokban tevékenykedő üzletkötők számára egy másik ágazat? Vajon a banki területen kellően motivált üzletkötőt a biztosítás, a pénzügyi tanácsadás területén is hasonló módon és a már korábban bevált, konkrét eszközökkel kellene ösztönözni? Esetleg egy másik pénzügyi területen betöltött értékesítői munkakör további inspiráló eszközöket kívánna meg ugyanazon üzletkötő esetében?

\section{Felhasznált irodalom}

Aon Hewitt (2016). 2016 Trends in global employee engagement - Employee engagement is on the rise, but volatility abounds. http://aonhewitt.hu/kutatasaink/ nemzetkozi-kutatasok/ Letöltve: 2016. november 17.

Aon Magyarország (2014). Legjobb Munkahely Felmérés 2014 - Erösödö elkötelezettség, növekvő kihívások - Trendek és tanulságok. http://aonhewitt.hu/kutatasaink/hazai-kutatasi-eredmenyek/ Letöltve: 2016. november 17.

Aon Magyarország (2016). Aon Legjobb Munkahelyek program - Elkötelezettség trendek és tanulságok. http://aonhewitt.hu/kutatasaink/hazai-kutatasi-eredmenyek/ Letöltve: 2016. november 17.

Armstrong, M. (1991). A handbook of personnel management practice. London, UK: Kogan Page. doi: 10.1177/009102609102000401

Bakacsi Gy. (2007). Szervezeti magatartás és vezetés. Budapest, Magyarország: AULA Kiadó Kft.

Bakacsi Gy. (2010). A szervezeti magatartás alapjai Alapszakos jegyzet a Budapesti Corvinus Egyetem alapszakos hallgató számára. Budapest, Magyarország: AULA Kiadó Kft. https://www.tankonyvtar.hu/ hu/tartalom/tamop425/2011_0001_543_07_A_szervezeti_magatartas_alapjai/ch06.htm $\bar{l} \#$ ftn.id508893 Letöltve: 2019. március 18.

Borgulya I. \& Barakonyi K. (2004). Vállalati kultúra. Budapest, Magyarország: Nemzeti Tankönyvkiadó Rt.

Carver, C.S. \& Scheier, M.F. (2006). Személyiségpszichológia. Budapest, Magyarország: Osiris Kiadó.

Dobák M. \& Antal Zs. (2010). Vezetés és szervezés - Szervezetek kialakitása és müködtetése. Budapest, Magyarország: AULA Kiadó Kft.

Farkas F., Jarjabka Á., Lóránd B., \& Bálint B. (2013). Munkahelyi motivációk Magyarországon 2013-ban. Vezetéstudomány, 44(10), 12-23.

Fodor M. (2010). Miért dolgozunk? Munkaügyi Szemle, (4), 41-47.

Fowler, S. (2015). Motiváció magasabb szinten. Budapest, Magyarország: HVG Kiadó Zrt.

Gyökér I. (2006). Szervezeti viselkedés - Tesztek - Oktatási segédanyag. Budapest, Magyarország: Budapesti Müszaki és Gazdaságtudományi Egyetem, Menedzsment és Vállalatgazdaságtan Tanszék, MBA program.

Ingram, T.N., \& LaForge, R.W. (1992). Sales management: Analysis and decision making. Fort Worth, TX: The Dryden Press.

Juhász I. (2014a). Kínai munkavállalók motiválásának vezetői kihívásai - kulturális sajátosságok, mint korlátok és mint lehetőségek. Marketing \& Menedzsment, 48(2), 71-82.

Juhász I. (2014b). Kínai munkavállalók motiválásának alternatívái - Hofstede kulturális dimenzióinak tükrében. Vezetéstudomány, 45(10), 58-67.

Kajos A., \& Bálint B. (2014). A marketingszemlélet és a HR találkozása - A munkáltatói márkaépítés értelmezése, irodalma és kutatási irányai. Vezetéstudomány, 45(6), 69-79. 
Klein S. (2001). Vezetés- és szervezetpszichológia. Budaörs, Magyarország: SHL Hungary Kft.

Kozák A. - Krajcsák Z. (2018). The effect of wages and work experiences on the commitment of Hungarian employees. Business: Theory and Practice, (19), 123134., Litvánia.

Központi Statisztikai Hivatal (2016). Népszámlálás 2011. szakstatisztikusi lekérdezés, egyéni kérés alapján, https://kapcsolat.ksh.hu/ContactCenter/ugyworeg. xhtml?megerositokod=28a5a7a6-968f-49f9-b68f8c19d0b52b81\&lang=hu Letöltve: 2016. szeptember 09.

Központi Statisztikai Hivatal (2019). Az alkalmazásban állók havi bruttó átlagkeresete a nemzetgazdaságban. http://www.ksh.hu/docs/hun/xstadat/xstadat evkozi/e_qli007a.html?back=/stadat_ker Leöltve: 2019. március 22.

Krasz K. (2009). A motiváció és a munkahelyi teljesítmény. In Bali K., Bodnár G., Juhász M., Krasz K., Laufer L., \& Takács I. Pszichológia (pp. 49-79), Budapest, Magyarország: Typotex Kiadó.

Kun Á. (2010). Munkahelyi jóllét és elköteleződés. Munkaügyi Szemle, 54(2), 35-41.

Lazear, E.P. (2006). A humán erőforrások közgazdaságtana vállalati vezetők részére. Budapest, Magyarország: Nemzeti Tankönyvkiadó Zrt.

Lussier, R.N. (1990). Human relations in organizations: A skill building approach. Homewood, IL: Richard D. Irwin.

Lussier, R.N. (1993). Human relations in organizations: A skill building approach (2nd ed.). Homewood, IL: Richard D. Irwin.

McClelland, D.C. (1965). Achievement motivation can be developed. Harvard Business Review, November-December.

Mitev A. Z. (2008). Toborzás és kiválasztás. In Bauer A. \& Mitev A. Z. (szerk.), Eladásmenedzsment (pp. 151166), Budapest, Magyarország: Akadémia Kiadó.
Radó A., \& Réthy I. (2011). Vezetési ismeretek. Budapest, Magyarország: Saldo Pénzügyi Tanácsadó és Informatikai Zrt.

Robbins, S.P., \& Judge, T. (1993). Organizational behavior (6th ed.). Englewood Cliffs, NJ: Prentice Hall International.

Roóz J. (2001). Vezetésmódszertan. Budapest, Magyarország: Perfekt Gazdasági Tanácsadó, Oktató és Kiadó Részvénytársaság.

Schultheiss, O.C., \& Brunstein, J.C. (2002). Inhibited power motivation and persuasive communication: A Lens model analysis. Journal of Personality, 70(4), 553-582, doi: 10.1111/1467-6494.05014

Shankle, G. (1992). Aerobics, movie tickets, swimming pools, day care: A paycheck is just the beginning in the employee benefits game. Indianapolis Business Journal.

Steers, R., \& Braunstein, D. (1976). A behavioralyly based measure of manifest needs in work settings. Journal of Vocational Behavior, (Oct.), 251-266. doi: 10.1016/0001-8791(76)90083-X

Takács S., Csillag S., Kiss Cs., \& Szilas, R. (2012). Még egyszer a motivációról, avagy „Hogyan ösztönözzük alkalmazottainkat itt és most?" Vezetéstudomány, 43(2), 2-17.

Tóth É. M. (2007). Karrieriskola. Budapest, Magyarország: HVG Kiadó Zrt.

Tóthné S. G. (2012). Motivációs és javadalmazási rendszerek. In Csordás T., Dabasi H. Zs., Dobay P., Juhász I., Kádek I., Majó Z., ... Zémán Z. (2012). Emberi eröforrás gazdálkodás (pp. 253-300), Budapest, Magyarország: CompLex Kiadó Jogi és Üzleti Tartalomszolgáltató $\mathrm{Kft}$.

Zsámboki B. (2000). A bankrendszer jövője (egy kérdőíves felmérés alapján). Budapest, Magyarország: Magyar Nemzeti Bank Bankföosztálya, Budapest. http:// mek.oszk.hu/03600/03692/03692.pdf Letöltve: 2016. október 27. 